\title{
Crime at the Intersection of Rail and Retail
}

Andrew Newton

The University of Huddersfield

\begin{abstract}
This chapter examines shoplifting at rail station shops over a 12 month period in England and Wales. Key findings were: shoplifting is concentrated at particular stations; the top 20 stations account for $85 \%$ of shoplifting. Clear temporal patterns were evident; shoplifting was higher on weekdays and during holidays with higher levels of travel; shoplifting is lower when there is a reduced rail service. There was no clear relationship between shoplifting rates outside of a station at shops nearby, and shoplifting within a rail station. It is suggested a correlation may occur for medium and smaller size stations. Large stations may attract offenders in their own right without other shops being nearby. The similarities observed between shoplifting patterns at rail stations and those at non-rail station shops suggest the learning from successful crime prevention measures applied outside of the rail environment could successfully transferred to rail stations.
\end{abstract}

Keywords: Shoplifting, rail, retail, crime, public transport 


\section{Introduction}

This study is motivated by three factors. Firstly, there has been a growing research interest into crime on public transport (Ceccato, 2013; Ceccato and Newton, 2015; Marteache and Bischler, 2016; Newton, 2014). Secondly, with the exception of cyber-crime and fraud, shoplifting is one of the few crime types in England and Wales to have increased over the past decade. This increase is also evident at shops located inside rail stations. However, despite this identified trend, no known studies have explicitly explored shoplifting at rail station shops. Thirdly, it is evident that rail stations are becoming more diverse. They no longer exist purely as a form of transport. For example, large stations now contain entertainment facilities and shopping centres which might make them more susceptible to shoplifting. Taking these three factors together, it is therefore argued that research into shoplifting at rail stations shops is both timely and necessary.

\section{Aims and research questions}

The aim of this research is to examine patterns of shoplifting at rail stations in England and Wales. In order to achieve this four research questions (RQs) have been identified.

- RQ1: Is shoplifting concentrated at particular rail stations?

- RQ2: What temporal patterns of shoplifting at rail stations are evident?

- RQ3: What type of shops are most victimised; and what types of merchandise are most commonly stolen from railway shops?

- RQ4: Is there any relationship between shoplifting at stations (rail station shops) and shoplifting in the vicinity of stations (non-rail station shops nearby)?

\section{Definitions}

For the purposes of this study, shoplifting is defined as 'the theft of goods from retail establishments carried out by non-employees during an establishment's opening hours' 
(adapted from Smith, 2013, p5). Shoplifting is also referred to as 'shop theft', 'shrinkage' and 'boosting'. For this study the term shrinkage is avoided, because in the transportation literature this term is also used to describe technological approaches to reduce travel time and increase journey efficiency (Newton, 2016). For consistency, the term shoplifting will be used hereafter.

\section{Context}

In England and Wales there has been a steady increase over the past 10 years in shoplifting recorded at rail station shops (Figure 1a). Outside of the rail environment, a similar picture of increasing levels of shoplifting is evident (Figure 1b). These increases have been identified internationally, for example in Finland (Kajalo and Lindlom, 2015). This is not consistent with the more general crime trends in England and Wales. Over the past decade crime rates, excluding cyber-crime and fraud, have been steadily declining (Figure 1c). This general decline in crime rates has also been observed on the rail environment (Newton, 2014). Therefore in England and Wales over the past decade, shoplifting in general, and shoplifting specifically at rail station shops, is increasing against a national and international picture of decreasing crime rates.

\section{Figures la to 1c about here}

\section{Theft at rail stations}

Few studies have examined commercial victimisation at the intersection of rail and retail. Uittenbogaard and Ceccato (2014) examined theft at rail stations in Stockholm but their analysis aggregated three crime types, robbery, burglary, and theft, into a single category of property crime. They found shoplifting accounted for one fifth of thefts at stations. In contrast, Ashby, Bowers, Borrion, Fujiyama (2017) found shoplifting accounted for $8 \%$ of thefts on rail in England and Wales. This difference may be a result of: differing recording 
practices; how shoplifting in rail environments is categorised; differing levels of reporting; or cultural differences between cities or countries. However, as few (if any) studies have explicitly explored shoplifting at rail stations, international comparisons are limited. Some studies have explored theft and transport more generally: Marteache and Bischler (2016) examined theft from baggage at US Airports; Sidebottom and Johnson (2014) investigated bicycle theft at stations; Gentry (2015) analysed theft of mobile phones; and Newton, Partridge and Gill (2014a, 2014b) explored pickpocketing on the London Underground. However, for all these studies the victims are the rail passengers or staff rather than commercial business. Due to the paucity of studies that explicitly examine shoplifting at rail stations, and as shoplifting is perhaps different to other types of theft, it is therefore necessary to draw upon the findings of studies into shoplifting from outside of the rail environment.

\section{Shoplifting outside of the rail environment}

Clarke (2012) and Smith (2013) highlight a range of key factors relevant to studying shoplifting including: the potential offenders involved; their Modus Operandi (MO); the geography of shoplifting including the spatial and temporal patterns of offending; the merchandise most at risk of being stolen; the type of premise from which items are stolen; the security and place management of shops; and the difficulties in accurately measuring and recording levels of shoplifting. As the data available for this research does not include MO data for shoplifting this is not explicitly discussed here, although is highlighted as an important avenue for further research.

\section{Theoretical explanations for shoplifting: offender type}

As with all crime types, no singly accepted theoretical explanation of shoplifting exists. Before attempting to distil possible explanations of shoplifting it is useful to consider the different types of shoplifters who may operate. Carmel-Gilfilen (2011) identified two types 
of shoplifter; 'experts' and 'novice' offenders; which Clarke (2012) expanded to three core types; 'petty' offenders, 'more determined' offenders, and 'organised gangs'.

Perhaps the most widely accepted explanation for shoplifting is that it is an opportunistic crime (Hayes, 1999). This is underpinned by studies linking shoplifting to routine activity perspective and rational choice theory (Salmi, Kivivuori, and Lehti, 2015; and Smith, 2013). Tonglet (2002, p336) suggests shoplifting decisions are influenced by 'pro-shoplifting attitudes, social factors, opportunities, and perceptions of low risks of apprehension'. Here opportunity is explicitly stated as part of the offender decision making process. The study also ties in with rational choice perspective identifying both the low risks of being caught and pro-shoplifting attitudes. Smith (2013) suggests many shoplifting offenders are juveniles. The findings of these studies all support the notion of shoplifting as opportunistic. This is perhaps most likely for 'novice' and 'petty' offender types, although it is acknowledged this is not all encompassing, for example not all juveniles will be 'novice' or 'petty' offenders.

However, there are criticisms of the opportunity model. Smith (2013) found alternative explanations for shoplifting included stealing to fund a drug habit, and to provide food for an offender's family. Katz (1998) identifies the 'sneaky thrills' of shoplifting and its 'seductive psychic and social rewards'. The previously quoted Tonglet study highlighted social factors as important, and there are motivational differences between shoplifting: 'to feed a family'; 'to feed a drugs habit'; and 'to make a profit'. Offenders who shoplift for the first two reasons may fall within the 'more determined' shoplifter type, and thus the 'rationality' of their decisions, a central component of the opportunity theory of crime, could be questioned. Katz's 1998 study also revealed alternative explanations of shoplifting included the social status associated with being a gang member. Whilst this supports Clarke's third shoplifter typology of 'organised gangs' the extent to which these offenders are opportunistic is also questionable. A central consideration here is whether any or all of these offender types may 
operate within the rail environment. It is suggested an argument can be made for all. However, to explore this further it is useful to consider the geographical patterns of shoplifting, the types of product stolen, and nature of stores present within rail stations.

\section{Spatial and temporal patterns of shoplifting}

If shoplifting is accepted as mostly an opportunistic crime, then it is likely to be clustered at certain locations and particular times (Newton, 2014). A key question here is the extent to which shoplifting is concentrated at particular stations, the notion of risky facilities (Marteache and Bichler, 2016). One of the more comprehensive studies into the spatial and temporal distribution of shoplifting was carried out by Nelson (1996) in Cardiff, Wales. A key finding was locations with high levels of shopping activity in the busiest areas of city centre were more vulnerable to shoplifting. There were also clear temporal patterns to offences, both seasonal peaks (pre-Easter, pre-Christmas and Pre-summer) and an increase in offences towards the end of week. When considering the spatial and temporal patterns of shoplifting at rail station shops, there are perhaps two critical questions. The first is the extent to which high passenger usage at rail stations is a factor in shoplifting. Examples of busy times include rush hour weekday peak travel times and holiday times. Another interesting dimension is whether shoplifters use stations as part of their day to day travel activity, and learn about opportunities to offend through this, or they visit rail station shops solely for the purpose of offending. The first links to the idea of crime generators and the second crime attractors, and both may be possible at rail stations (Newton, 2014). The extent to which rail station shoplifting is concentrated at particular stations and possible seasonal trends are explored in research questions 1 and 2.

\section{Premise types and at-risk merchandise}

Smith (2013) argues that shoplifters are attracted to expensive and luxurious products, which supports the 'more determined' and 'organised gang' offender typologies. However, Smith 
also suggests that much shoplifting involves the theft of lower-priced 'everyday' products such as razor blades, deodorants, fresh meat, vitamins, and over the counter drugs. Offenders stealing these goods are perhaps more likely to be 'novice' and 'petty' offender although again these are not exclusive to each type. Table 1 adapted from previous studies (Bamfield, 2004; Clarke, 2012; Smith, 2013) highlights a range of products stolen by shoplifters and the stores from which these are commonly taken. The final adapted column of this table considers whether these shop types are generally present at rail stations. Research question 3 examines the vulnerability of different types of shops at rail stations to shoplifting, and the products more likely to be stolen. If the goods stolen and types of shops targeted at rail stations are comparable to those observed outside of rail stations, then an argument can be made that prevention mechanisms used to deter theft within stores outside of railway stations are potentially transferrable to the rail environment.

\section{Table 1 about here}

Within the crime and public transport literature an important issues is the extent to which crime at public transport stations is correlated with crime in the surrounding environment. This is termed spatial interplay (Robinson and Gordiano, 2011). Newton (2014) showed most studies have found a positive correlation between crime at stations and crime in surrounding environments. However, the author noted this is not always the case. In Washington, DC, Metro, good design has been shown to be a protective factor at stations situated in high crime settings. Newton et. al, (2014b) found that pickpocketing on the London Underground was correlated to pickpocketing levels in the surrounding environs of stations, but that pickpocketing and shoplifting were not correlated. Therefore a key question to be explored for this study is whether shoplifting at rail stations is related to shoplifting that occurs at shops in the nearby vicinity of stations. 


\section{The measurement of shoplifting}

This study uses two sources of recorded crime, captured from the British Transport Police (BTP), and the 43 police forces of England and Wales. One of the limitations of using police records is they are known to underestimate levels of shoplifting; many offences are not reported to the police as businesses deal with them 'in house'. Other reasons for poor reporting of shoplifting are: poor record keeping and stock taking; and, or, the inability of a shop to determine whether missing stock can be attributed to shoplifting or not. All policerecorded shoplifting incidents would also require the apprehension of an offender, or at least the shoplifting act being witnessed even if the offender was not caught. Alternative measures to capture reliable shoplifting levels include the British Retail Consortium (BRC) Retail Crime Survey and the Commercial Victimisation Survey (2014 onwards). However, neither of these disaggregates data for rail stations. Carmel-Gilfilen (2011) suggests shoplifting data could also be captured from: self-reported offender surveys; store detective and retail loss prevention department records; and information gathered from apprehended shoplifters. These have been criticised as indirect measures and subject to possible bias and they may also therefore underestimate shoplifting levels (Farrington and Burrows, 1993). Other potential data capture avenues include systematic observation and counting and assessment of security-related products. As this study is thought to be the first to explicitly examine shoplifting at rail stations, it uses BTP recorded crime data on shoplifting which is collected on a station by station basis.

\section{Data}

Data on shoplifting at rail station shops was captured from the British Transport Police (BTP); the national police force for railways in England, Wales and Scotland. The data used in this study includes stations in England and Wales only, and excludes those on the London Underground, although London over-ground stations are included. Shoplifting records were 
captured for the period January 2012 to December 2012 using BTP crime category J22; theft by shoplifting. Fields extracted included rail station name, date, type of premise, and description of the property. There were 1,682 shoplifting offences recorded at stations for this time period.

To distinguish between very large stations and smaller rural stations which may not contain any shops, shoplifting data was combined with the Department for Transport's classification of rail stations. This categorises stations into six categories A to F (Table 2). Over $99 \%$ of shoplifting occurs at stations classed A to D, therefore all subsequent analyses in this chapter only includes shoplifting offences within category A to D stations (see Table 3). Thus the analysis presented hereafter examines 1,670 shoplifting offences which occurred at 96 out of 588 over-ground rail stations in England and Wales.

\section{Table 2 about here}

Shoplifting at non-rail station shops was captured from police recorded shoplifting using open source (https://data/police/uk/) for the same 2012 time period. All BTP recorded crime was separated from this. Additional other non-station crime data was also extracted including burglary, violence, theft and criminal damage. The information extracted included month of offence and location, and geographical co-ordinates. This was aggregated to Lower Super Output Area (LSOA), aggregated census unit with an average of roughly 1,500 residents and 650 households. LSOAs are clustered using measures of proximity to give a reasonably compact shape to encourage grouping of areas of similar social background.

\section{Methods}

The Pareto principle states for many events approximately $80 \%$ of the effect comes from $20 \%$ of the cause (Marteache and Bischler, 2016). Translated into shoplifting at stations, this suggests that $80 \%$ of shoplifting may be found at about $20 \%$ of rail stations. A Resource 
Target Table (RTT) was produced to answer research question 1; the extent to which shoplifting is concentrated at particular stations. Previous studies have found shoplifting has particular seasonal trends with increases just before and during typical holidays, and tends to happen towards the end of the week. Research question 2 examined shoplifting using two methods: by the day of week; and also by the week of the year (over 52 weeks) and descriptive frequencies were produced for each.

Research question 3 examined the shop types at stations which experienced shoplifting, and the types of merchandise stolen. This analysis required manual reclassification of free text fields into author-defined categories developed using categories found in the literature. In addition the value of merchandise stolen in each shoplifting offence was estimated and categorised to the nearest pound as: 'under $£ 10$ '; ‘ $£ 10-20$; ' $£ 21-50$ '; ‘ $£ 51-200$; and ' $£ 201$ ' or more. Whilst this information was provided in the product description field about $50 \%$ of the time, much of this has been manually estimated using the description of the items stolen. Frequencies were then calculated for the types of premises victimised, the types of merchandise stolen, and the value of the goods taken.

In order to examine the relationship between shoplifting at rail station shops and shoplifting in the nearby vicinity of stores (RQ4) two methodologies were employed. At LSOA level, Spearman's rank correlations were used to explore if a relationship was evident between shoplifting at stores in the non-rail environment, with rail store shoplifting. Additionally a group comparison test was used for non-station shoplifting between LSOAs with shopliftingaffected stations and non-shoplifting affected stations.

\section{Results}

An analysis of shoplifting by station type revealed concentrations of shoplifting at particular rail stations. 28 stations are classed as category A and 24 of them (86\%) experienced at least 
one shoplifting offence. Indeed $75 \%$ of shoplifting occurred at Category A stations. 30 out of 62 type B stations experienced at least one shoplifting offence, and $12 \%$ of all shoplifting occurred at type B stations. Thus, $87 \%$ of shoplifting occurred at class A and B stations. Approximately $12 \%$ of class $\mathrm{C}$ and fewer than $5 \%$ of class D stations experienced any shoplifting, and these stations together accounted for $12 \%$ of all station shoplifting.

\section{Table 3 about here}

\section{Concentrations of shoplifting}

To explore these concentrations further an RTT of shoplifting by stations was produced which demonstrated this clustering of crimes at only a few stations (see Table 4): the top 10 stations for shoplifting (1.7\% of all stations) experienced $66 \%$ of all shoplifting $(1,109$ offences); 9 out of 10 of these were type A stations and one type B; and $85 \%$ of shoplifting occurred at the top 20 stations, equivalent to $3 \%$ of all stations. All top 20 stations for shoplifting were type A or B. This demonstrates the applicability of the $80 / 20$ rule of crime concentration to shoplifting. The top station for shoplifting experienced 297 offences, nearly one fifth of all shoplifting reported in 586 stations. However, two category A stations and 37 category B stations did not experience any shoplifting. Thus shoplifting is not purely a function of larger or busier stations.

\section{Table 4 about here}

\section{Temporal trends in shoplifting}

Research question 2 examined the temporal and seasonal patterns of shoplifting. Figure 2 shows the distribution of shoplifting across the year across all A to D stations. There are three clear peaks: late February/early March around school half term; late April around Easter; and late June or early July at the start of the summer holidays. Surprisingly there was no peak at Christmas although there is a slightly reduced rail service at this time. After each peak, there 
is a distinct drop in shoplifting. Figure 3 depicts shoplifting offences by the day of the week. Patterns of shoplifting are fairly consistent during weekdays although slightly higher on Wednesdays and Thursdays. This rate is reduced on Saturdays when there is a reduced service, and the lowest rates of shoplifting are found on Sundays. This is reflective of rail patronage. The daily pattern of shoplifting at rail station shops is therefore slightly at odds with shops outside of the rail environment, where rates tend to increase towards the end of the week and Saturdays. These findings suggest the daily temporal patterns of rail store shoplifting are consistent with passenger levels and train operating times. This suggests shoplifters prefer busier shops when staff can be more easily distracted. It is not clear at busy times if offenders are present at stations as part of their usual journeys, or if they target rail station stores at peak hours and holiday periods deliberately.

\section{Figure 2 about here}

Figure 3 about here

\section{Goods stolen and types of rail shops at risk of shoplifting}

Research question 3 explored the types of premises at risk of shoplifting at rail stations (see Table 5) and the types of merchandise frequently stolen (Table 6). It is evident that the majority of shoplifting occurs at kiosk/shops/stores (83\%). Unfortunately it is difficult to break this down further due to the nature of the recording by BTP. A limitation here is it is not clear how many of each type of shop is present within each station, or what volume of goods (possible available targets) are present within each store.

\section{Table 5 about here}

The analysis reveals the most commonly shoplifted products are food and alcohol. These products were stolen in $64 \%$ of shoplifting offences. Ten percent of shoplifting offences involved the theft of beauty products, a further $10 \%$ was clothing, and just over $3 \%$ stationary 
goods. Other items stolen include electronics, jewellery, over-the-counter drugs, flowers, and cigarettes.

\section{Table 6 about here}

Analysis of the value of stolen products found: $50 \%$ of shoplifting was for goods totalling under $£ 10,16 \%$ for $£ 11-20 ; 18 \%$ for $£ 21-50 ; 9 \%$ for $£ 10-200$, and $3 \%$ more than $£ 200$ (see Table 7). This suggests novice, more determined, and possibly even organised gangs may all carry out shoplifting at stations. However, it is important to note that an increase in the value of the items stolen does not always equate to an increase in the expertise or determination of the shoplifter. When examining alcohol, food and soft drinks, over $60 \%$ of shoplifting was of goods valued at under $£ 10$. However, $3 \%$ of the shoplifting of food and soft drinks was of goods worth £51-200, and 7\% of alcohol stolen was worth £51-200. This may indicate a mixture of both novice and more determined shoplifters. When considering more expensive products such as clothing, electronics and jewellery it was evident offenders focussed on goods at the higher price range. $37 \%$ of electronic items stolen, $15 \%$ of jewellery stolen, and $10 \%$ of clothing stolen was valued at more than $£ 200$. Whilst no information was available on the MO used, the value of and types of good stolen are indicative or different types of offenders being active. In some instances entire shelves were cleared, which could, but does not necessarily suggest a high degree of planning and organisation. In other cases, sandwiches, stationary and soft drinks valued at less than $£ 2$ were stolen.

\section{Table 7 about here}

The final research question concerned the relationship between shoplifting at rail stations and shoplifting in the vicinity of rail stations. Shoplifting at stations (BTP) and non-stations (police crime) were aggregated by LSOAs to compare the relationship between the two. A Spearman's rank correlation between station-shoplifting and non-station shoplifting 
aggregated at LSOA revealed a weak but statistically significant correlation between the two $(\mathrm{N}=575$, rho=.131, $\mathrm{p}=0.002)$. There was a stronger correlation between station-shoplifting and non-station other crime $(\mathrm{N}=575, \mathrm{rho}=.264,-=0.000)$. This other crime variable included theft, violence, criminal damage and other theft. Thus station shoplifting seemed to be more likely in LSOAs with high levels of non-station other crime in general, rather than in LSOAs with high levels of non-station shoplifting. Given that many LSOAs experienced zero stationshoplifting offences the analysis was re-run to include only LSOAs with stations that experienced shoplifting. The results were: for station-shoplifting with non-station shoplifting, $\mathrm{N}=85$, rho=0.97, $\mathrm{p}=.377$; and for station-shoplifting with non-station other crime, $\mathrm{N}=85$, rho $=.442, \mathrm{p}=0.000$. Here the slight relationship between station-shoplifting and non-station dropped to non-significant. In contrast there was a stronger correlation between station shoplifting and non-station other crimes. Thus shoplifting was higher in high crime areas, but these were not necessarily the same areas that experienced high levels of shoplifting.

To explore this relationship further, correlations between station-shoplifting and non-station shoplifting at LSOAs were examined by station type, 'A', 'B', 'C' and 'D'. The only significant relationship was found between type B station-shoplifting and non-station shoplifting $(\mathrm{N}=575$, rho=.128, $\mathrm{p}=0.002)$. No significant correlations where found with other station types. When comparing shoplifting at each category of station with other crime outside of the station, there were significant correlations for category ' $A$ ' stations $(N=575$, rho=.207,p=0.000), category ' $\mathrm{B}$ ' stations $(\mathrm{N}=575$, rho=.159, $\mathrm{p}=0.000)$ and category ' $\mathrm{C}$ ' stations $(\mathrm{N}=575, \mathrm{rho}=.091, \mathrm{p}=.029)$. This suggests that shoplifting in areas with high levels of non-station shoplifting is correlated, but this holds true for type ' $\mathrm{B}$ ' mid-size stations. Where shoplifting occurs in the largest type ' $A$ ' stations, this is not correlated with shoplifting outside the station. In terms of general crime levels, there is a stronger correlation between 
larger size stations with shoplifting and other non-shoplifting crime outside of the station, and this decreases as station size reduces.

To test this further, group comparison tests were used to compare LSOAs with station shoplifting to non-station shoplifting, and LSOAs without station shoplifting to non-station shoplifting. The results of this showed a significant difference $(N=575, U=16464.5, p=0.002)$ which suggest non-station shoplifting in LSOAs that experienced station shoplifting (mean rank $=339.3$ ) was significantly higher than LSOAs were there was no station-shoplifting (mean rank=279.1). However, when comparing non-station other crimes with station shoplifting, a similar result was found $(\mathrm{N}=575, \mathrm{U}=12272, \mathrm{p}=0.000)$. As 5 LSOA areas contained more than one station (four of these had two stations, and one had four stations), all the above analysis, both the correlations and the group comparisons were repeated excluding these 5 LSOA. However, no changes to the above reported significance results were found.

It is therefore suggested that although there is a correlation between shoplifting at stations and non-station shoplifting, this relationship is not straight forward. For type 'A' stations is it likely that they are a large enough attractor for offenders in their own right, irrespective of nearby shoplifting opportunities. In contrast for type ' $\mathrm{B}$ ' stations, there is a correlation between station-shoplifting and non-station shoplifting. Thus the size of a station is important. The degree of connectedness of the larger and medium size stations may also have a role to play here. Large train stations may in their own right become a suitable target for shoplifting, but for medium size stations it seems evident that offenders may prefer opportunities where shoplifting opportunities are present both within and near to stations. Rail stations may form part of an offenders travel routine, and shops at rail stations may then form part of their awareness space. Alternatively, shops at stations may be considered a suitable target for offenders who do not use stations to travel, or a combination of both may apply. 


\section{Discussion of findings}

This study, perhaps the first to examine shoplifting at rail stations, found shoplifting is concentrated at a small proportion of rail stations. Indeed the top 20 stations of nearly 2500 rail stations accounted for $85 \%$ of all shoplifting. The temporal pattern of shoplifting at stations suggested shoplifting follows busy travel periods with higher passenger numbers. Unfortunately data on the time of day of shoplifting was not available. Seasonal trends were evident, with peaks at the start of holiday periods when travel demand is high. The exception here is Christmas, when there is often a reduced rail service in operation. A range of different products were stolen consistent with those identified in the literature as high risk. Examples include food and alcohol, beauty products, clothing, electronic goods, jewellery, over-thecounter drugs, and flowers. The value of these items ranged from a few pounds to over $£ 800$. Stolen food and alcohol items included small snacks and sandwiches, but also premium and high value steaks and champagne. Similar patterns were identified between shoplifting at stations and outside of stations, including spatial and temporal patterns and the types of products stolen. This suggests lessons learned from reducing shoplifting outside of stations should be transferrable to shops within rail stations.

Whilst there were similarities between theft at station shops and theft at non-station shops, a key difference is the differing opening hours and busy periods. Shopliftings rates at stations are influenced by rail passenger volume which fluctuates based on peak and off-peak travel times and station opening times. This argument is supported by the reduced level of shoplifting found at stations on Saturdays, unlike shops in main urban shopping centres. It is not possible to determine using the available data whether shoplifters at stations use the station purely for shoplifting, or for the combined purpose of travel and shoplifting. The findings as to whether stations in areas that have high levels of shoplifting in general were mixed. Correlations were not found between BTP rail shoplifting and non-rail shoplifting at 
LSOAs. However, the group comparison analysis found that stations which had experienced shoplifting had statistically significantly higher levels of police recorded shoplifting (nonrail) than those areas that did not. It may be that the smaller medium size category ' $\mathrm{B}$ ' stations are more susceptible to shoplifting when they are in high crime areas. In contrast the larger stations 'A' may attract offenders to them on their own merit. A factor not considered in this analysis is how well a station is connected to other stations as how central or peripheral a station is, as in other studies this has been shown to influence crime levels.

\section{Limitations of study}

There are a number of limitations to this study. The BTP and police-recorded crime data is subject to under-reporting as discussed previously. It is not clear if recording is better at some stations than others, or if certain stores report shoplifting more frequently, which may also account for the concentrations evident at stations. There is no time stamp so it is not possible to compare shoplifting between peak and off-peak travel times. There is no information on offender MO, and the classification of premise type and what is stolen was not recorded consistently and required manual cleaning and re-classifying. The study also does not include denominators of shoplifting; the results produced are frequencies or counts of shoplifting of offences. However, this may be influenced by the number of and types of shops present at rail stations, and the number of passengers who use a station. The proportion of different types of products available at stations may also influence shoplifting patterns. Thus standardising shoplifting as a rate (per product/per passenger/per shop) is particularly challenging. The spatial analyses disaggregated BTP and police-recorded crime at LSOAs. However, this may not be refined or disaggregated enough to pick up correlations between at stations and near stations. A more refined analysis using buffer analysis rather than using LSOAs may offer more robust evidence thus further research here is warranted. The study also does not take account of any prevention schemes already in place in stores to combat shoplifting. 


\section{Implications for policy}

The findings of this research suggest situational prevention measures successfully used outside of rail stations to reduce shoplifting could be transferred to shops within rail stations. These include: establishing a shoplifting policy and making all staff/customers aware; staff training; improved physical security including displaying dummy goods, using security cabinets for high value products, displaying warning notices, using mirrors and improving line of sight and visibility; establishing anti-shoplifting partnerships with other organisations; ensuring adequate staffing levels; not displaying high-value goods near entrances or exits; using customer greeting to interact with customers and ensure and to let potential offenders know you are being watched; enforcement of regular stock monitoring; banning known shoplifters; and using tagging devices and access control.

However, good design also needs to consider the shopping experience, key to a business's success. The introduction of new prevention measures should not affected sales, which means certain situational crime prevention measures such as keeping high-value items locked up and the use of display cases for products of high value goods, which then requires a staff member to access them for the customer can be problematic. Kajalo and Lindblom (2015) discuss the need to balance a secure shopping environment with one that is a pleasant environment for shoppers.

In addition it may be that the design and management of stations themselves, the routine policing, monitoring and surveillance carried out by BTP and station managers could potentially be tailored to reduce shoplifting. For example situational prevention measures can also be extended to rail foyers outside of shops, reducing blind corners and maximising surveillance opportunities for staff; posting clear messages that shoplifters will be prosecuted; and even hiring more and better staff who can interact with customers in a pleasant and friendly way. 


\section{Potential avenues for future research}

A range of future research has been highlighted by this study. An analysis of the MO used by offenders, combined with types of products stolen and from which premises, should enable a better profiling of the types of offenders who shoplift at rail stations. Interviews with offenders may offer additional insights here. A better recording of premise type and more accurate information on value of products would also increase the reliability of the findings. More meaningful classifications are offered by Guy (1998), the UK government classification of retail goods, and the Business Statistics Office.

A clear challenge is how to develop consistent methods to account for denominators in shoplifting to compare rates. This could include passenger volumes, the number of customers in stores, and the proportion of different types of goods available. Rates of shoplifting by passenger levels might not be appropriate as many may not use rail station shops. Additional information on the types and size of shops at each station would allow further identification of station similarity in terms of measuring shoplifting opportunities. The spatial analysis should also be further refined. An alternative to LSOA $s$ is to use buffer analysis around stations. A key question to be explored is whether large retail environments are at higher risk if they have stations near them. Similarly, it would be helpful to determine if station shops experience higher levels of shoplifting if there are several shops in the vicinity of the station.

Finally, this chapter does not include any analysis of interventions specifically introduced to reduce shoplifting at train stations. There is no assessment of the levels of security at stores within a station. Fieldworker observations of the security measures in place at stations would improve the reliability of the findings. This would aid our understanding as to the extent to which situational crime reduction measures at shops can be transferred explicitly to shops found in railway stations. 


\section{References}

Ashby, M., Bowers, K., Borrion, H. and Fujiyama, T. (2017). The when and where of an emerging crime type: The example of metal theft from the railway network of Great Britain. Security Journal: 30 (1), 1-23

Bamfield, J. (2004). Shrinkage, shoplifting and the cost of retail crime in Europe: a crosssectional analysis of major retailers in 16 European countries. International Journal of Retail and Distribution Management: 32 (5), 235-241

Carmel-Gilfilen, C. (2011). Advancing Retail Security Design: Uncovering Shoplifter Perceptions of the Physical Environment. Journal of Interior Design: 36, 21-38

Ceccato, V. (2013). Moving Safely: Crime and Perceived Safety in Stockholm's Subway Stations. Lanham, MD. Lexington books

Ceccato, V. and Newton, A. (2015) (Eds.). Safety and Security in Transit Environments: An Interdisciplinary Approach. Crime Prevention and Security Management: London, UK: Palgrave Macmillan

Clarke, R. (2012). Shoplifting: Problem-Oriented Guides for Police Problem-Specific Guides Series No. 11 (2nd Edition). Washington DC. U.S. Department of Justice Office of Community Oriented Policing Services

Farrington, D. and Burrows, J. (1993). Did shoplifting really decrease? British Journal of Criminology: 33 (1), 57-69

Gentry, K. (2015). Apple Picking: The Rise of Electronic Device Thefts in Boston Subways, in Ceccato, V. and Newton, A. (Eds.), Safety and Security in Transit Environments: An Interdisciplinary Approach. Hampshire, UK. Palgrave Macmillan, pp 39-55

Guy, C. (1998). Classifications of retail stores and shopping centres: some methodological issues. GeoJournal: 45 (255), 255-264

Hayes, R. (1999). Shop Theft: An Analysis of Shoplifter Perceptions and Situational Factors. Security Journal: 12 (2), 7-18

Kajalo, S. and Lindblom, A. (2015). Creating a safe and pleasant shopping environment: a retailer's view. Property Management: 33 (3), 275 - 286

Marteache, N., and Bichler, G. (2016). Crime Prevention and Transportation Systems: In Winterdyk, J. and Raton. B. (Eds): Crime Prevention: International Perspectives, Issues, and Trends. Florida, USA: CRC Press pp65-90

Nelson. A. (1996). The geography of shoplifting in a British city: Evidence from Cardiff. Geoforum: 27 (3), 409-423 
Newton, A (2014). Crime on Public Transport, in Bruinsma, G. and Weisburd, D. (Eds.): Encyclopedia of Criminology and Criminal Justice. New York, NY: Springer, pp. 709-720

Newton, A (2016). Crime, Transport and Technology, in Mcguire, M. and Holt, T. (Eds): The Routledge Handbook of Technology, Crime and Justice. London, UK: Routledge

Newton, A., Partridge, H. and Gill, A. (2014a). Above and below: measuring crime risk in and around underground mass transit systems. Crime Science: 3 (1), pp. 1-14

Newton, A., Partridge, H. and Gill, A. (2014b): In and around: Identifying predictors of theft within and near to major mass underground transit systems. Security Journal: 27 (2), $132-$ 146

Newton, A (2016) 'Crime, Transport and Technology': In McGuire, M. and Holt, T. (Eds). The Routledge Handbook of Technology, Crime and Justice: London, UK: Routledge. pp. 281-294

Reddy, A. V., Kuhls, J., \& Lu, A. (2011): Measuring and controlling subway fare evasion: Improving safety and security at New York City Transit Authority. Transportation Research Record: 2216, 85-99

Robinson, J, \& Goridano, L. (2011). Spatial Interplay: Interaction of Land Uses in Relation to Crime Incidents around Transit Stations, in Andresen, M. and Kinney, B. (Eds.). Patterns, Prevention, and Geometry of Crime. London: Routledge, pp. 175-199

Salmi, V., Kivivuori, J. and Lehti, M. (2015) Public disorder and business crime victimization in the retail sector. Security Journal: 28 (4), 410-424

Sidebottom, A., \& Johnson, S. D. (2014) Bicycle theft, in Bruinsma, G. and Weisburd, D. (Eds.), Encyclopedia of Criminology and Criminal Justice. New York, NY: Springer, pp. $162-170$

Smith, B. (2013) Differential shoplifting risks of fast-moving consumer goods: A dissertation submitted to the Graduate School, Newark Rutgers, The State University of New Jersey. Unpublished PhD Thesis

Tonglet, M. (2002). Consumer misbehaviour: An exploratory study of shoplifting. Journal of Consumer Behaviour: 1 (4), 336-354

Uittenbogaard, A. \& Ceccato, V. (2014): Safety in Stockholm's Underground Stations: An Agenda for Action. European Journal on Criminal Policy and Research: 20 (1), 73-100 


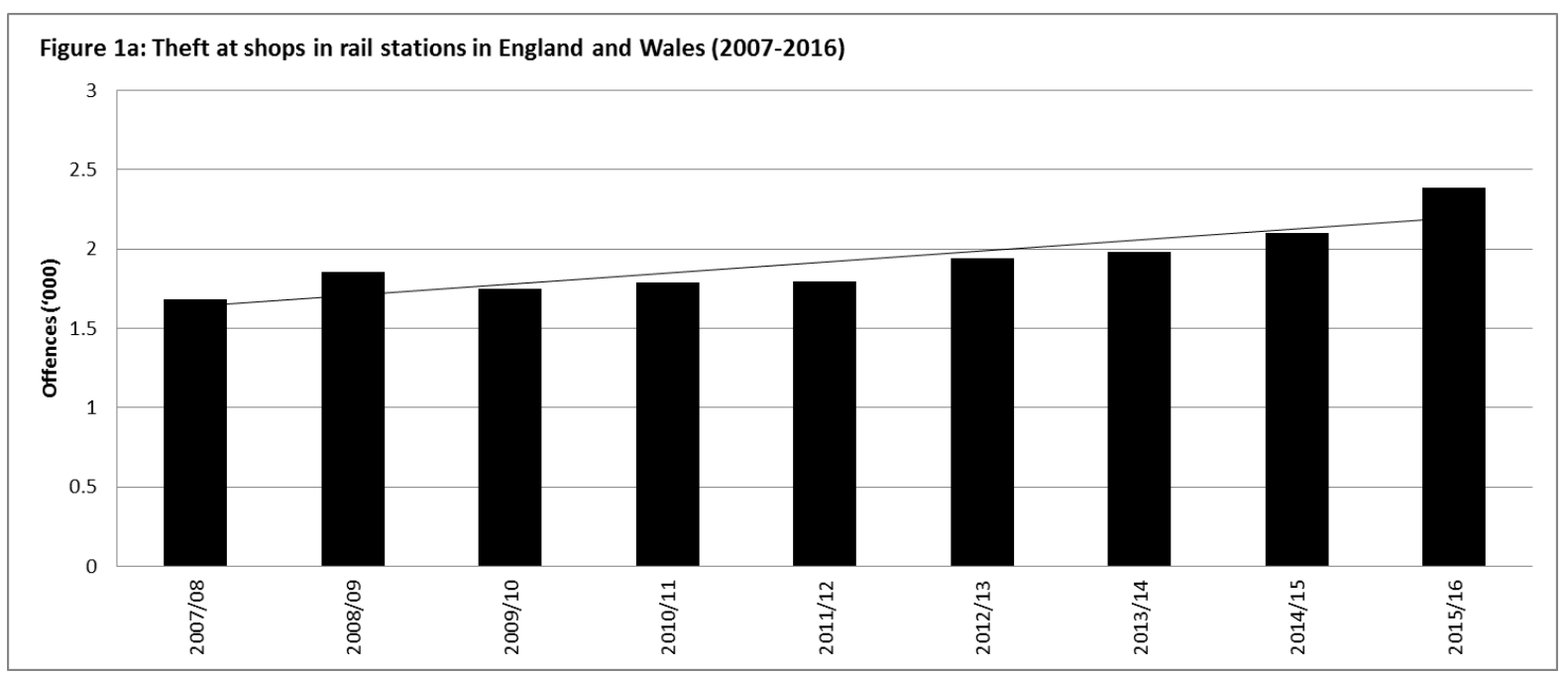

Source: British Transport Police Annual Crime Reports

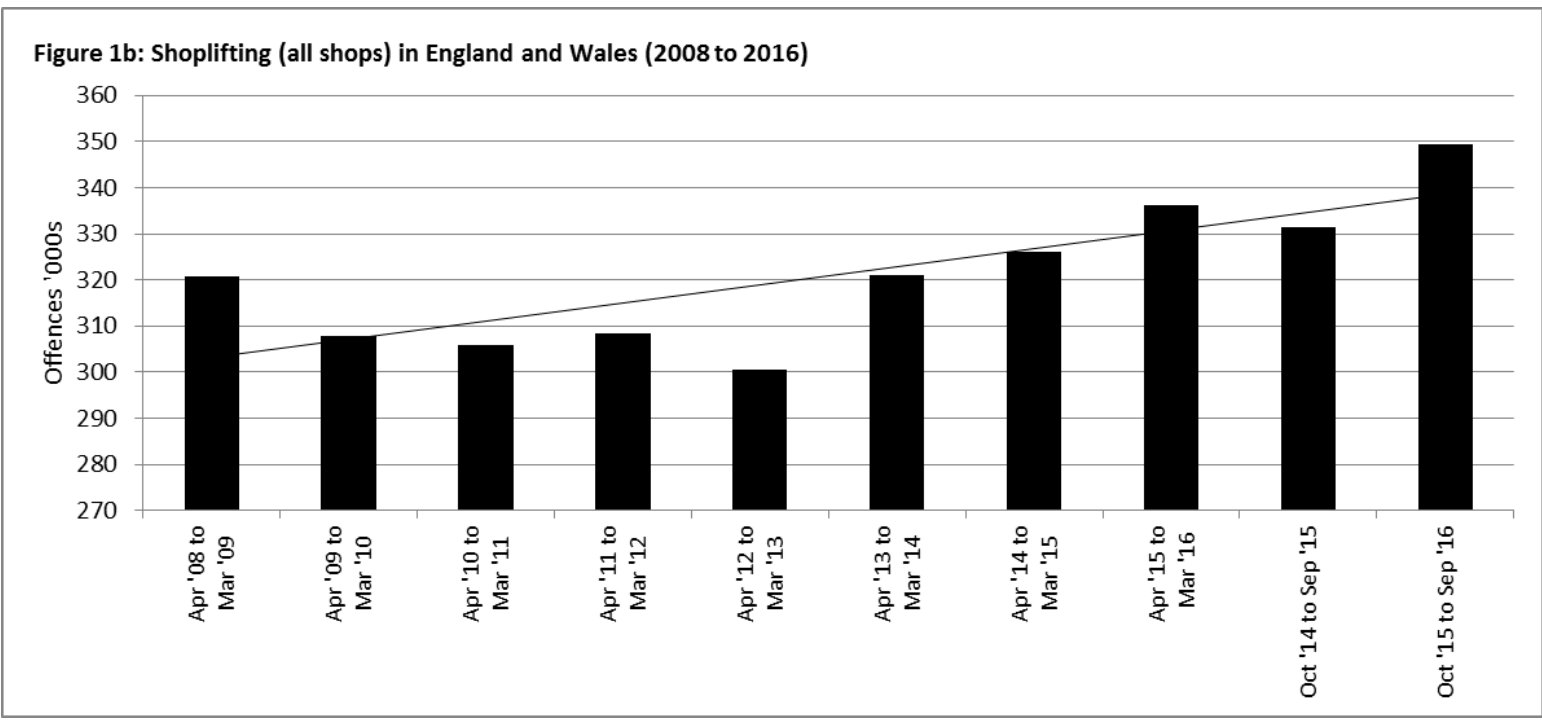

Source: Home Office Annual British Crime Survey/ Crime Survey for England and Wales (CSEW)

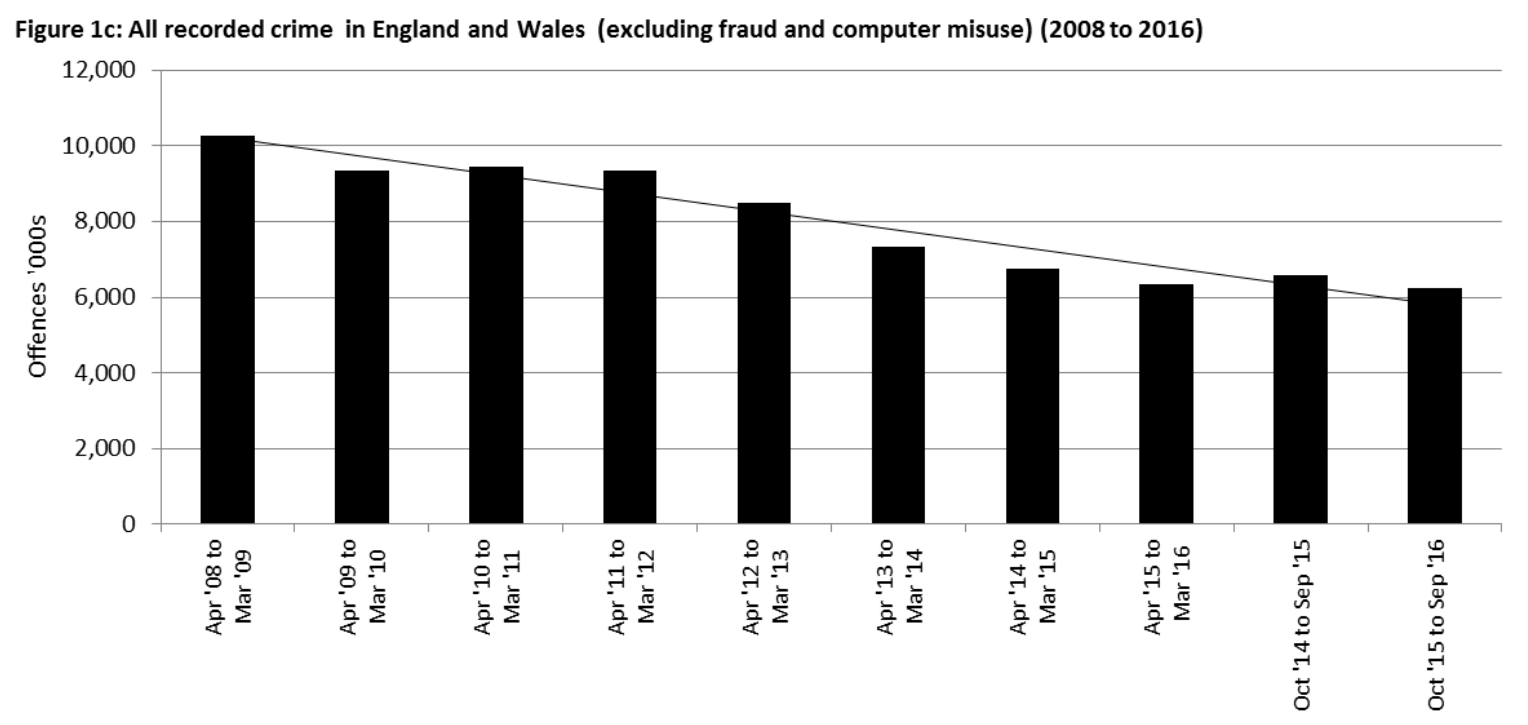

Source: Home Office Annual British Crime Survey/ Crime Survey for England and Wales (CSEW) 


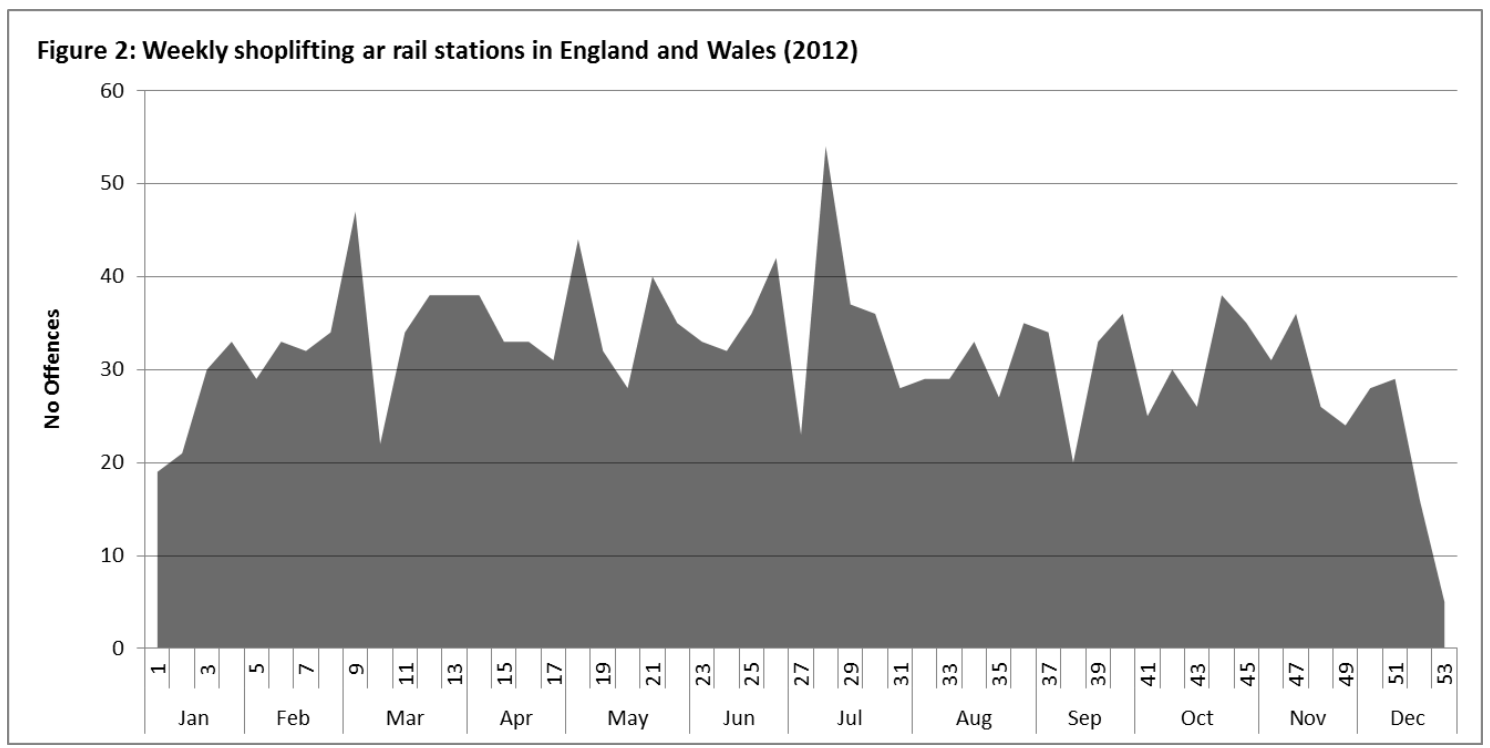

Source: British Transport Police

Figure 3: Shoplifting at rail stations by day of week (2012)

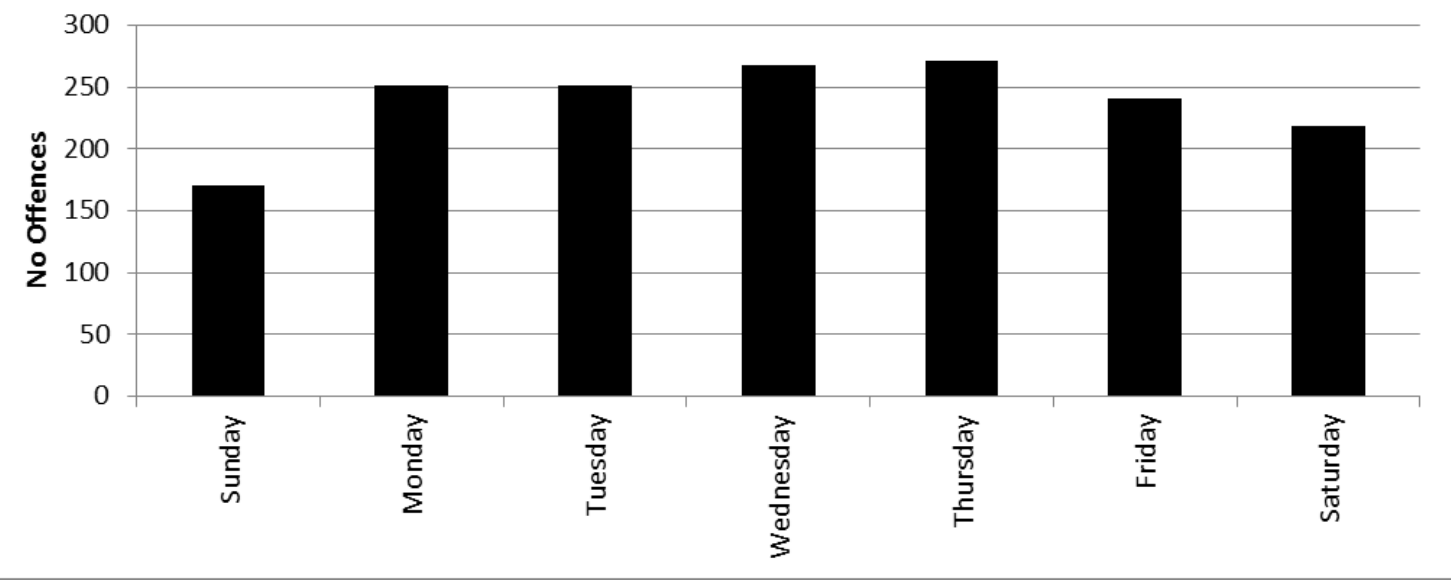

Source: Source: British Transport Police 
Table 1: High-risk products by shop type (adapted from Bamfield, 2004; Clarke, 2012; and Smith, 2013)

\begin{tabular}{|l|l|l|}
\hline Shop type & Product & $\begin{array}{l}\text { Stores } \\
\text { frequently } \\
\text { found at rail } \\
\text { stations }\end{array}$ \\
\hline Auto/car parts & $\begin{array}{l}\text { Small accessories, dash covers, } \\
\text { satellite navigation systems, driving } \\
\text { gloves }\end{array}$ & No \\
\hline Clothing shops & $\begin{array}{l}\text { Clothing, shirts, dresses, handbags, } \\
\text { shoes, purses and wallets, designer } \\
\text { fashion, watches and jewellery, } \\
\text { fashion accessories, socks, scarves, } \\
\text { sportswear }\end{array}$ & Yes \\
\hline Drug/pharmacy & $\begin{array}{l}\text { Cigarettes, batteries, over the counter } \\
\text { remedies, small electric items, shaving } \\
\text { products and razor blades, perfumes }\end{array}$ & Yes \\
\hline Hardware & Hand tools & No \\
\hline $\begin{array}{l}\text { Music/video/game } \\
\text { s/ entertainment }\end{array}$ & $\begin{array}{l}\text { CDs, DVDs, gaming devices, } \\
\text { computer games }\end{array}$ & Yes \\
\hline $\begin{array}{l}\text { Mobile phone } \\
\text { shops }\end{array}$ & $\begin{array}{l}\text { Mobile phones, tablets, mobile phone } \\
\text { covers }\end{array}$ & Yes \\
\hline Theme parks & Key chains, jewellery & No \\
\hline $\begin{array}{l}\text { Supermarkets } \\
\text { (local metro stores) }\end{array}$ & $\begin{array}{l}\text { Food, over-the-counter remedies, } \\
\text { health and beauty products, cigarettes, } \\
\text { batteries, fresh meat*, alcohol, shaving } \\
\text { products and razor blades, perfumes, } \\
\text { chocolates, flowers }\end{array}$ & Yes \\
\hline Stationers & $\begin{array}{l}\text { CDs, DVDs, magazines and } \\
\text { newspapers }\end{array}$ & Yes \\
\hline Toy shops & Yction figures \\
\hline
\end{tabular}

* Perishable goods not always viewed as high-risk (see Smith, 2013). 
Table 2: Station classification (England and Wales)

\begin{tabular}{|c|c|c|c|}
\hline $\begin{array}{l}\text { Station } \\
\text { Type }\end{array}$ & $\begin{array}{l}\text { Number } \\
\text { of } \\
\text { Stations }\end{array}$ & $\begin{array}{l}\text { Type of } \\
\text { Station }\end{array}$ & $\begin{array}{l}\text { Trips per } \\
\text { annum }\end{array}$ \\
\hline A & 28 & $\begin{array}{r}\text { National } \\
\text { hub }\end{array}$ & $\begin{array}{c}\text { over } 2 \\
\text { million }\end{array}$ \\
\hline B & 62 & $\begin{array}{r}\text { Regional } \\
\text { interchange }\end{array}$ & $\begin{array}{r}\text { over } 2 \\
\text { million }\end{array}$ \\
\hline $\mathrm{C}$ & 236 & $\begin{array}{r}\text { Important } \\
\text { feeder }\end{array}$ & $0.5-2$ million \\
\hline $\mathrm{D}$ & 262 & $\begin{array}{r}\text { Medium, } \\
\text { staffed }\end{array}$ & $\begin{array}{r}0.25-0.5 \\
\text { million }\end{array}$ \\
\hline $\mathrm{E}$ & 591 & $\begin{array}{l}\text { Small, } \\
\text { staffed }\end{array}$ & $\begin{array}{r}\text { under } 0.25 \\
\text { million }\end{array}$ \\
\hline $\mathrm{F}$ & 996 & $\begin{array}{r}\text { Small, } \\
\text { unstaffed }\end{array}$ & $\begin{array}{r}\text { under } 0.25 \\
\text { million }\end{array}$ \\
\hline
\end{tabular}


Table 3: Shoplifting offences at rail stations by station type (2011/2012)

\begin{tabular}{|c|c|c|c|c|c|c|c|c|}
\hline Station type & A & B & $\mathrm{C}$ & $\mathrm{D}$ & $\begin{array}{c}\text { Sub } \\
\text { Total 1 } \\
\text { (Stations } \\
\text { A to D) } \\
\end{array}$ & $\mathrm{E}$ & $\mathrm{F}$ & $\begin{array}{c}\text { Sub } \\
\text { Total } 2 \\
\text { (Stations } \\
\text { A to F) } \\
\end{array}$ \\
\hline Number of stations & 28 & 62 & 236 & 262 & 588 & 591 & 996 & 2,282 \\
\hline $\begin{array}{l}\text { Number of stations with } \\
\text { at least one shoplifting } \\
\text { offence }\end{array}$ & 24 & 30 & 29 & 13 & 96 & 4 & 5 & 105 \\
\hline $\begin{array}{l}\text { Percentage of stations } \\
\text { with at least one } \\
\text { shoplifting offences }\end{array}$ & 85.7 & 48.4 & 12.3 & 5.0 & 16.3 & 0.7 & 0.5 & 4.6 \\
\hline $\begin{array}{l}\text { Number of shoplifting } \\
\text { offences }\end{array}$ & 1,259 & 206 & 114 & 91 & 1670 & 6 & 6 & 1,682 \\
\hline $\begin{array}{l}\text { Percentage of all } \\
\text { shoplifting offences }\end{array}$ & 74.9 & 12.2 & 6.8 & 5.4 & 99.3 & 0.4 & 0.4 & 100.0 \\
\hline
\end{tabular}


Table 4: Concentrations of shoplifting at rail stations (2011/2012)

\begin{tabular}{|c|c|c|c|c|c|c|c|c|c|}
\hline $\begin{array}{l}\text { Anonym- } \\
\text { ised } \\
\text { station } \\
\text { number }\end{array}$ & $\begin{array}{l}\text { Station } \\
\text { category }\end{array}$ & $\begin{array}{l}\text { Number of } \\
\text { shoplifting } \\
\text { offences }\end{array}$ & $\begin{array}{l}\text { Number } \\
\text { of } \\
\text { stations }\end{array}$ & $\begin{array}{l}\text { Cumulative } \\
\text { frequency } \\
\text { shoplifting } \\
\text { offences }\end{array}$ & $\begin{array}{l}\text { Cumulative } \\
\text { frequency } \\
\text { of stations }\end{array}$ & $\begin{array}{l}\% \text { of } \\
\text { shoplifting } \\
\text { offences }\end{array}$ & $\begin{array}{l}\% \text { of } \\
\text { stations }\end{array}$ & $\begin{array}{l}\text { Cumul- } \\
\text { ative \% of } \\
\text { shoplifting } \\
\text { offences }\end{array}$ & $\begin{array}{l}\text { Cumul- } \\
\text { ative \% } \\
\text { of } \\
\text { stations } \\
\end{array}$ \\
\hline 1 & $\mathrm{~A}$ & 297 & 1 & 297 & 1 & 17.8 & 0.2 & 17.8 & 0.2 \\
\hline 2 & A & 146 & 1 & 443 & 2 & 8.7 & 0.2 & 26.5 & 0.4 \\
\hline 3 & A & 134 & 1 & 577 & 3 & 8.0 & 0.2 & 34.6 & 0.5 \\
\hline 4 & A & 120 & 1 & 697 & 4 & 7.2 & 0.2 & 41.7 & 0.7 \\
\hline 5 & $\mathrm{~A}$ & 96 & 1 & 793 & 5 & 5.7 & 0.2 & 47.5 & 0.9 \\
\hline 6 & A & 70 & 1 & 863 & 6 & 4.2 & 0.2 & 51.7 & 1.1 \\
\hline 7 & $\mathrm{~A}$ & 66 & 1 & 929 & 7 & 4.0 & 0.2 & 55.6 & 1.2 \\
\hline 8 & $\mathrm{~B}$ & 65 & 1 & 994 & 8 & 3.9 & 0.2 & 59.5 & 1.4 \\
\hline 9 & A & 63 & 1 & 1,057 & 9 & 3.8 & 0.2 & 63.3 & 1.6 \\
\hline \multirow[t]{7}{*}{10} & A & 52 & 1 & 1,109 & 10 & 3.1 & 0.2 & 66.4 & 1.7 \\
\hline & & 20 to 50 & 10 & 1,413 & 20 & 18.2 & 1.7 & 84.6 & 3.4 \\
\hline & & 10 to 19 & 8 & 1,430 & 21 & 6.3 & 1.4 & 85.6 & 4.8 \\
\hline & & 5 to 9 & 7 & 1,519 & 28 & 3.1 & 1.2 & 91.0 & 6.0 \\
\hline & & 2 to 4 & 24 & 1,633 & 59 & 3.8 & 4.1 & 97.8 & 10.1 \\
\hline & & 1 & 37 & 1,670 & 96 & 2.2 & 6.3 & 100.0 & 16.4 \\
\hline & & 0 & 492 & 1,670 & 588 & 0.0 & 83.7 & 100.0 & 100.0 \\
\hline Total & & 1670 & 588 & na & na & 100.0 & 15.0 & na & na \\
\hline
\end{tabular}


Table 5: Premises that experienced shoplifting at stations (2012)

\begin{tabular}{|l|r|r|}
\hline Premise Type & $\begin{array}{l}\text { Number of } \\
\text { shoplifting } \\
\text { offences }\end{array}$ & $\begin{array}{l}\text { \% of } \\
\text { shoplifting } \\
\text { offences }\end{array}$ \\
\hline Kiosk/shop/store & 1391 & 83.3 \\
\hline Tenant premises & 92 & 5.5 \\
\hline Coffee shop & 66 & 4.0 \\
\hline Other & 35 & 2.1 \\
\hline Supermarket & 27 & 1.6 \\
\hline $\begin{array}{l}\text { Chemist } \\
\text { shop/pharmacy }\end{array}$ & 25 & 1.5 \\
\hline Station newsagent & 20 & 1.2 \\
\hline $\begin{array}{l}\text { Burger bar/fast food } \\
\text { outlet }\end{array}$ & 14 & 0.8 \\
\hline Total & 1670 & 100 \\
\hline
\end{tabular}


Table 6: Types and frequency of merchandise shoplifted at rail stations (2012)

\begin{tabular}{|l|r|r|}
\hline Merchandise category & $\begin{array}{l}\text { Number } \\
\text { of } \\
\text { shoplifting } \\
\text { offences }\end{array}$ & $\begin{array}{l}\text { Percentage } \\
\text { of } \\
\text { shoplifting } \\
\text { offences }\end{array}$ \\
\hline Food/soft drinks & 722 & 43.2 \\
\hline Alcohol (no food) & 350 & 21.0 \\
\hline Beauty products & 173 & 10.4 \\
\hline Clothing & 153 & 9.2 \\
\hline Stationary & 61 & 3.7 \\
\hline Other & 56 & 3.4 \\
\hline Alcohol and food & 42 & 2.5 \\
\hline Electronics & 35 & 2.1 \\
\hline Jewellery & 32 & 1.9 \\
\hline Drugs (over-the-counter) & 19 & 1.1 \\
\hline Flowers & 15 & 0.9 \\
\hline Cigarettes & 12 & 0.7 \\
\hline Total & 1670 & 100.0 \\
\hline
\end{tabular}


Table 7: Value and frequency of goods shoplifted at rail stations (2012)

\begin{tabular}{|c|c|c|c|c|c|c|c|}
\hline \multirow{2}{*}{\multicolumn{2}{|c|}{ Merchandise Category }} & \multirow{2}{*}{\multicolumn{6}{|c|}{ Value of shoplifted merchandise }} \\
\hline & & & & & & & \\
\hline Food & $\mathrm{N}$ & $\begin{array}{c}\text { under } \\
£ 10 \\
577\end{array}$ & $\begin{array}{c}£ 11- \\
20 \\
71\end{array}$ & $\begin{array}{c}£ 21- \\
50 \\
53\end{array}$ & $\begin{array}{c}£ 51- \\
200 \\
19 \\
\end{array}$ & $\begin{array}{r}£ 200+ \\
2 \\
\end{array}$ & $\begin{array}{r}\text { Total } \\
722 \\
\end{array}$ \\
\hline drinks & $\%$ & $(79.9)$ & $(9.8)$ & $(7.3)$ & $(2.6)$ & $(0.3)$ & \\
\hline \multirow[t]{2}{*}{ Alcohol only } & $\mathrm{N}$ & 221 & 68 & 37 & 24 & 0 & 350 \\
\hline & $\%$ & $(63.1)$ & $(19.4)$ & $(10.6)$ & $(6.9)$ & $(0.0)$ & \\
\hline \multirow[t]{2}{*}{ Beauty products } & $\mathrm{N}$ & 12 & 35 & 86 & 34 & 6 & 173 \\
\hline & $\%$ & $(6.9)$ & $(20.2)$ & $(49.7)$ & $(19.7)$ & $(3.5)$ & \\
\hline \multirow[t]{2}{*}{ Clothing } & $\mathrm{N}$ & 5 & 27 & 59 & 44 & 18 & 153 \\
\hline & $\%$ & $(3.3)$ & $(17.6)$ & $(38.6)$ & $(28.8)$ & $(11.8)$ & \\
\hline \multirow[t]{2}{*}{ Other } & $\mathrm{N}$ & 18 & 9 & 20 & 5 & 4 & 56 \\
\hline & $\%$ & $(32.1)$ & $(16.1)$ & $(35.7)$ & (8.9) & $(7.1)$ & \\
\hline \multirow[t]{2}{*}{ Alcohol and food } & $\mathrm{N}$ & 18 & 16 & 5 & 3 & 0 & 42 \\
\hline & $\%$ & $(42.9)$ & $(38.1)$ & $(11.9)$ & $(7.1)$ & $(0.0)$ & \\
\hline \multirow[t]{2}{*}{ Electronics } & $\mathrm{N}$ & 1 & 5 & 8 & 8 & 13 & 35 \\
\hline & $\%$ & $(2.9)$ & $(14.3)$ & $(22.9)$ & $(22.9)$ & $(37.1)$ & \\
\hline \multirow[t]{2}{*}{ Jewellery } & $\mathrm{N}$ & 1 & 6 & 14 & 6 & 5 & 32 \\
\hline & $\%$ & (3.1) & $(18.8)$ & $(43.8)$ & $(18.8)$ & $(15.6)$ & \\
\hline \multirow[t]{2}{*}{$\begin{array}{l}\text { Drugs (over-the- } \\
\text { counter) }\end{array}$} & $\mathrm{N}$ & 4 & 9 & 2 & 4 & 0 & 19 \\
\hline & $\%$ & $(21.1)$ & $(47.4)$ & $(10.5)$ & $(21.1)$ & $(0.0)$ & \\
\hline \multirow[t]{2}{*}{ Flowers } & $\mathrm{N}$ & 6 & 5 & 4 & 0 & 0 & 15 \\
\hline & $\%$ & $(40.0)$ & $(33.3)$ & $(26.7)$ & $(0.0)$ & $(0.0)$ & \\
\hline \multirow[t]{2}{*}{ Cigarettes } & $\mathrm{N}$ & 4 & 4 & 4 & 0 & 0 & 12 \\
\hline & $\%$ & $(33.3)$ & $(33.3)$ & $(33.3)$ & $(0.0)$ & $(0.0)$ & \\
\hline
\end{tabular}

